See discussions, stats, and author profiles for this publication at: https://www.researchgate.net/publication/335620602

\title{
Assessing the role of collaboration in the process of museum innovation
}

Article in Journal of Cultural Economy · September 2019

DOI: 10.1080/17530350.2019.1643392

CITATION

1

2 authors:

Chuan Li

University of Valencia

12 PUBLICATIONS 7 CITATIONS

SEE PROFILE

Some of the authors of this publication are also working on these related projects:

Designscapes View project

deaR. An R package for Data Envelopment Analysis View project
READS

69

Vicente Coll Serrano

University of Valencia

51 PUBLICATIONS 206 CITATIONS

SEE PROFILE 


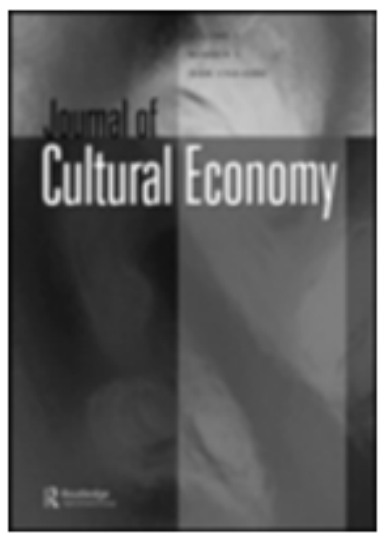

\section{Assessing the Role of Collaboration in the Process of Museum Innovation}

\begin{tabular}{|r|l|}
\hline Journal: & Journal of Cultural Economy \\
\hline Manuscript ID & RJCE-2018-0133.R1 \\
\hline Manuscript Type: & Original Article \\
\hline Keywords: & $\begin{array}{l}\text { museum, technological innovation, cultural innovation, cultural } \\
\text { production, collaboration }\end{array}$ \\
\hline
\end{tabular}

\section{SCHOLARONE}

Manuscripts

This is an Accepted Manuscript of an article published by Taylor \& Francis in Journal of Cultural Economy on September 5, 2019, available online: http:// www.tandfonline.com/10.1080/17530350.2019.1643392 .

To cite this article:

Chuan Li \& Vicente Coll-Serrano (2019) Assessing the role of collaboration in the process of museum innovation, Journal of Cultural Economy, DOI: 10.1080/17530350.2019.1643392 


\title{
Assessing the Role of Collaboration in the Process of Museum Innovation
}

\begin{abstract}
The relationship between collaboration and innovation in cultural organisations is an emerging topic that has drawn particular attention from scholars and practitioners. The main aim of this study is to assess the role of collaboration in the process of innovation in museum organisations. To achieve this aim, first, we develop a four-domain analytical framework by matching innovation types to cultural production processes to reflect the peculiarities of museum innovation. By applying this framework to the multiple case studies from four Spanish museums, we identify three main motivations (supplementing manpower, compensating for the scarcity of knowledge, improving demand-driven innovation) and four forms of collaboration (teamwork, outsourcing, consortium and conversation) and summarise the different modes of collaboration involved in various domains of production and innovation. An assessment is conducted subsequently to evaluate the effectiveness of existing collaborations in achieving technological and cultural innovation in museums. Finally, a list of implications for museums' innovation management is presented.
\end{abstract}

Keywords: museum, technological innovation, cultural innovation, cultural production, collaboration

\section{Introduction}

Innovation management in the cultural and creative sectors has been an emerging topic in recent years, among which the relationship between collaboration and innovation has received particular attention in academia. Overall, it is argued that collaboration is an important driving factor in facilitating the process of innovation in cultural and creative organisations. For example, Castro-Martínez and Fernández-Baca Casares (2012) assert that value-adding innovative products and services result, fundamentally, from extensive collaboration between cultural organizations and diverse knowledge providers at the production, distribution and consumption stages in Spanish heritage institutions. Such collaboration was also observed in new product development in the music 
industry: "new early music collection is the result of the collaboration between a record company and a public research organization" (Castro-Martínez et al. 2013).

Additionally, collaboration also improves innovation outputs, for instance, Verbano et al. (2008) discovered that Italian restoration firms that collaborated with firms and universities or research institutions are more likely to adopt new laser technology and to be more technologically innovative.

As cultural and creative organisations, museums also rely on collaboration for innovation. Camarero and Garrido (2012) found that collaboration with other museums in joint leisure and cultural activities is a necessary condition for visitor-oriented museums to generate technological innovation. Furthermore, Li and Ghirardi (2019) pointed out that the contribution of collaboration to museum innovation differs depending on the type of innovation, and that different collaborative arrangements also have different impacts on the innovation outcomes in museums.

The literature on this topic is, however, still scarce in comparison with that on the subject of innovation; moreover, most are aimed at identifying the relationship between collaboration and innovation by means of statistical analysis of the cultural organisations. Although these studies have contributed to this topic with many examples and evidence supporting possible causation between them, it is still unclear from existing literature how collaboration fits in the process of museum innovation.

Therefore, where prior studies can be viewed as exploring the 'know-what' knowledge, this study attempts to expand 'know-how' knowledge, and for that reason this article will concentrate mainly on two issues: (1) identifying the modes of collaboration involved in the process of innovation and production in today's museum organisations; and (2) assessing the effectiveness of these modes in driving museum innovation. 


\section{Collaboration as a Driving Factor of Innovation}

Collaboration can be defined as the mutual engagement of participants in a coordinated effort to solve the problem together, wherein collaborators share some common objectives in the clear division of labour. Collaboration is a pattern of action that often requires actors to cooperate with both insiders, e.g., workers in cross-functional teams, and outsiders from outside of the organisation to look for new knowledge (Granados and Pareja-Eastaway, 2019) and thus, fostering a networked environment to achieve some complex goals (Thomson et al. 2009), such as innovation. Because collaboration can be better at motivating effort and can allow creative people to work on projects more efficiently than would traditional mechanisms (Benkler, 2006), there is an increasing argument that collaboration could be an effective organisational strategy for improving project performance and innovation in a wide range of sectors, for example, from agriculture (Compagnucci and Spigarelli, 2018) and manufacturing (Schroth and Häußermann, 2018) to service (Ruiz-Torres et al., 2018), and cultural and creative sectors (Castro-Martínez, Recasens and Jiménez-Sáez, 2013; Li and Ghirardi, 2018). In addition, a recent study pointed out that there are inverted U-shaped relationships between collaboration breadth and radical innovation performance and between collaboration depth and incremental innovation performance (Kobarg, StumpfWollersheim and Welpe, 2019), which further reinforces such argument that collaboration can foster innovation.

Innovation is the multi-stage process of transforming ideas into new/improved products, services or processes, in order to advance, compete and differentiate organisations successfully in the marketplace (Baregheh et al. 2009). This definition can be understood in two aspects. On the one hand, the "novelty" of innovation can be measured by technological/functional improvement, meaning generation, or changes in 
organisational structure (Stoneman, 2010) and thus, categorising innovation into technological, cultural and organisational dimensions accordingly. On the other hand, successful commercialisation does not always mean the pursuit of economic benefit, but also for the purpose of delivering a social benefit, which especially occurs in arts and cultural organisations. Whilst admitting that the process of cultural production may involve changes in technology/function and organisational structures, the distinction between the cultural and creative sectors from the rest is creativity, and the generation or communication of symbolic meaning involved in mass production (Galloway and Dunlop, 2007). Therefore, innovation in arts and cultural organisations displays special features as opposed to the technological and functional dimensions and these features can be summarised as (1) content creativity (Handke, 2004), wherein creativity and other modes of innovation may feed into each other; (2) hidden innovation (Miles and Green, 2008), which is not registered by traditional innovation indicators and is reflected, mostly, in novel combinations of existing technologies and processes, and innovative problem-solving; and (3) soft innovation (Stoneman, 2010), which primarily impacts upon the aesthetic or intellectual appeal rather than how it performs at a functional level.

Collaboration typically takes place within and between organizational structures. Early innovation literature used to emphasise internal collaboration in Research and Development (R\&D) at large corporations, Schumpeter Mark II pattern (Schumpeter 1942 cited Malerba and Orsenigo 1995) is an example; whilst, in turn, recent literature stresses external collaboration by the adoption of external knowledge and technologies in an open innovation environment, as proposed by open innovation theory (Chesbrough 2003a). Due to the objectives of our study, this article focuses on external collaboration. 
In general, external collaboration comprises two types of interaction: userproducer and supplier-producer. User-producer interaction describes the collaboration between producers and potential users so as to transmit information about the in-use value of the new characteristics of a product to the final users of the innovation (Lundvall 1988); supplier-producer interaction focuses on the collaboration between upstream and downstream industries, as well as the integration of production, education and research activities in the innovation system (Fagerberg 2006). As far as museums are concerned, 'users' are always people - both, cultural creation and utilisation of new technologies, are at the service of the users; yet, the 'supplier' side refers to knowledge producing institutions that provide the knowledge and technologies necessary for production and innovation ( $\mathrm{Li}$ and Ghirardi 2019), e.g., technology firms (Verbano et al. 2008), universities (Zukauskaite 2012), and research centres (Castro-Martínez et al. 2013).

According to the innovation literature, the dependence of innovation on collaboration can be explained by the following considerations: first, in an economy characterized by the vertical division of labour and by ubiquitous innovation, a substantial part of innovative activities take place in units separated from the users of innovation, therefore, successful innovation requires collaborative learning for knowledge about the needs of potential users (Freeman et al. 1982, p. 124, Lundvall 1988); second, given enormous cost of $R \& D$ is enormous, it is more cost-efficient for organisations to implement external R\&D outcomes developed and patented by other firms and offered to the market through licensing agreements, joint ventures and other arrangements (Chesbrough 2003b); third, inter-firm collaboration can help share the costs and rewards of developing innovative activities, and thus mitigate somewhat the risks associated with the innovation process (Bureth et al. 1997). Here the first element 
concentrates on user-producer interaction whilst the latter two emphasise supplierproducer interaction.

In sum, innovation is an interactive process involving the transfer and creation of knowledge through organizational learning (Harkema 2003) and collaboration is an important means of knowledge exchange through direct interaction with users and suppliers (Bureth et al. 1997, Martin and Moodysson 2011).

However, the above explanation cannot be applied directly to the cultural and creative sectors or three reasons. First, the creative economy in many countries consists predominantly of small and medium-sized enterprises (SMEs) (UNCTAD 2008), which may lack the ability to innovate, or the capacity to contribute scarce internal resources to a collaborative project. Second, innovation literature typically focuses on R\&D and technological innovation over cultural innovation, which is further stressed by cultural organisations studies (Castañer 2014). Third, many art and cultural organisations are both cultural production units and experience sites, and thus, entailing extra features in terms of experience innovation (Sundbo 2009), which may have an impact on the modality of collaboration.

\section{An Analytical Framework}

Based on the previous discussion, it is reasonable to address the interrelation between collaboration, innovation and production to set the context of our study. On the one hand, while innovation commonly takes place in the process of production, the production itself is a process based on the repetition of certain routines developed from prior innovation (Lundvall 1988); on the other hand, collaboration is always dependent on the environment of innovation and production where it evolves.

It is for this that, in order to identify and assess the role of collaboration in museum innovation, it is first necessary to define an appropriate analytical framework 
based on the process of production and innovation that takes into account the specific characteristics of the museum organisations.

\section{Cultural Production and Experience}

In terms of the production process, museums display a dual nature: (1) productive units (Johnson and Thomas 1998), they manufacture products by which consumers can construct distinctive forms of individuality, self-affirmation and social display (Scott 2004); (2) they also are public experience institutions (Sundbo 2009) and, supply an entertainment, edification and information-based experience (Scott 2004). Experience is simultaneously co-produced with consumers through their engagement with the process of consumption (Hauknes 1998) and is mostly exemplified in intangible services such as visiting exhibitions, participating in educational events, buying at museum shops and using catering services, both online and on site.

Production and experience in a museum can be seen as two separate functions largely contained within different functional activities in the museum organisation. Conservation, exhibition, research and education are functional activities relating to production whilst communication and visitor service are associated with the experience side. For example, an exhibition is a cultural product, but visiting the exhibition is an experience because the process of visiting is, usually, a 'mental journey' (Sundbo 2009) delivering new knowledge or simple spiritual pleasure. Therefore, the utility of this experience is often evaluated at the individual level, depending on whether his or her needs were met or not. This requires suppliers of experience, i.e. museums, to segment their offer to reflect the interests of different stakeholder groups.

Production and experience place different demands on museum innovation. If innovation in production is more or less similar to R\&D and new product development, innovation in experiences is mostly based on quick ideas and employee and customer 
involvement and on customer-oriented problem-solving (Sundbo 2009). A market orientation strategy encourages museums to transform conventional curator-oriented production to visitor-oriented production (Camarero and Garrido 2012), thus strengthening the vital role of user-producer interaction in fostering innovation in cultural production.

\section{Technological and Cultural Innovation}

From a knowledge-based perspective, innovation is a process of knowledge creation (Plessis 2007), which mainly involves three bases of knowledge, namely, analytical, synthetic and symbolic, in the creative sectors (Asheim and Coenen 2005, Asheim, Coenen and Vang, 2007). In detail, an analytical knowledge base comprises predominantly scientific knowledge, wherein knowledge creation is based on cognitive and rational processes, or on formal models; a synthetic knowledge base comprises predominantly engineering knowledge, wherein knowledge creation usually relies on the accumulation and combination of existing knowledge in the course of seeking problem-solving solutions; a symbolic knowledge base comprises meaning, desire, aesthetic, quality, affect, intangibles, and symbols, and knowledge creation often refers to the creation of cultural meaning through transmission in an affecting sensuous medium.

Concerning arts and cultural organisations, therefore, innovation can be classified generally into two types in terms of the predominant knowledge base on which an innovative activity is based (Li and Ghirardi, 2018), i.e., technological innovation is mostly based on analytical and synthetic knowledge bases whilst cultural innovation is defined by symbolic knowledge base. Furthermore, they can be embodied in diverse forms according to some scholars. For example, technological innovation at least involves the use of external technologies (Costa Barbosa 2013) and internal R\&D (De- 
Miguel-Molina et al. 2013) and cultural innovation is often embedded in new cultural product development (Castañer and Campos 2002, Castañer 2014) and arts and humanities research (Bakhshi et al. 2008).

Based on the above discussion, we think such a taxonomy of innovation also can be applied empirically in museum organisations in terms of different disciplines on which museum staff are trained. Take Spanish museums as an example, as exhibited in figure 1, despite a wide range of disciplines, Spanish museums comprise mainly four knowledge bases - symbolic knowledge (83.8\%), managerial knowledge (12.1\%), synthetic knowledge (8.3\%) and analytical knowledge (5.5\%) - which constitute essential intelligent engines for different types of innovation within museum organisations. Here we add 'managerial knowledge' as competences concerning communication abilities, responsive behaviour and negotiation skills, which are believed to contribute to organizational innovation (OECD and Eurostat 2005), although not the focus of this study. In a few words, knowledge distribution in Spanish museums evidences that museums are symbolic knowledge-intensive organisations that rate poorly in terms of analytical and synthetic knowledge, which may further imply that museum organisations have more capacity for cultural innovation than technological innovation.

[Insert figure 1]

\section{Matching production process with innovation type}

From the different production processes and innovation types identified above, it is possible to classify production and innovation in museums into four areas:

- Technological innovation in the production domain

- Technological innovation in the experience domain 
- Cultural innovation in the production domain

- Cultural innovation in the experience domain

By doing so, different functional museum activities fall into each different domain, as illustrated in figure 2. For instance, all, digital device and experience, digital museum and exhibition, social media application, intranet, and online ticket and shopping, fall into the upper right corner of the figure, which suggests that they share certain common characteristics of technology adoption and experience innovation and thus, being categorised as an ideal type of experience-based technological innovation.

But this is not to say that all functional activities grouped together are homogeneous in their utilisation of knowledge and the process of value creation; conversely, they are scattered in the domain according to where they fall along the spectrum of the two dimensions in figure 2.

Furthermore, it is important to emphasise that the reality could be more complex than that is simplified here, not only for the diversity involved in the process of knowledge generation and value creation, but also for different goals, means, and conditions to which innovative activities may be subject in practice.

Taking the complicated way in which innovation occurs into consideration, however, it is necessary to conceptualise some theoretical stereotypes in order to construct an analytical framework for exploring the mode of collaboration focusing on specific domains where the different types of innovation take place.

[Insert figure 2]

In the following section, we study the examples of restoration, digitalisation, exhibition and visitor services as vehicles to further discuss the characteristics of innovation associated with each of the domains described above. 


\section{Innovation in Four Domains}

\section{Restoration}

Restoration involves actions taken to modify the existing material and structure of an object in order to return it to a new or original condition. Innovation in restoration means to develop options for material or structural improvements by employing new knowledge and techniques. The areas of action are "colour, form, signs of ageing and de-colouration, the content of salts and contamination, biodegrades, damage and deformation, and signs of usage" (ICOM-CC, 2018), which cover a wide range of analytical knowledge such as physics, biology and chemistry. Yet, the process of restoration relies on the application of synthetic knowledge base, such as laser technology and high-power microscopes. Therefore, restoration is an analytical and synthetic knowledge-intensive activity, in which technological innovation is involved.

\section{Digitalisation}

The digitalisation of the museum means the integration of cultural heritage and the digital techniques involved in functional activities to facilitate communication and enhance the visitor experience. Innovation in digital museum practice is mainly encapsulated by the development and utilisation of (1) digital (or digitalised) objects, (2) digital networks, e.g., website construction, (3) digital experience, e.g., 3-Dimensions and Virtual Reality in display, and (4) digital devices, e.g., information kiosks and Quick Respond (QR) codes (Costa Barbosa 2013), which aims at narrowing the distance between museums and their prospective and actual visitors, physically and intellectually, as well as enriching the visiting experience. Therefore, it can be regarded as an experience-based technological innovation. 


\section{Exhibition}

Exhibitions are hallmark cultural products delivered by museums to their audiences. Considering that an exhibition is "a communication medium based on objects and their complementary elements ... use special interpretation techniques and learning sequences that aim at transmission and communication of concepts, values and/or knowledge" (Herreman 2004), the fundamental nature of museum exhibition is storytelling (Bedford 2001) and innovation in exhibition is exemplified by new storytelling approaches and new concepts, values and/or knowledge transmitted and communicated. The introduction of new technologies in an existing exhibition may improve the visitor experience, but it doesn't alter its nature because technologies cannot create meaning and value. Therefore, innovation in the exhibition can be seen as a production-based cultural innovation.

\section{Visitor services}

Museums usually concentrate their "public experience" assets in visitor services, which focus on the provision of an informative, pleasant and comfortable visit to museumgoers in the physical, intellectual and social sense (Woollard 2004). Since public experience is closely related to consumer demand, innovation in visitor services is demand-driven and manages to improve the quality and accessibility of visitor services to different user groups. In museums, visitors' preferences and tourist appeal often constitute tacit and symbolic knowledge embedded in the interpersonal interaction between museums and their audience. For this reason, innovation in visitor services can be regarded as an experience-based cultural innovation.

\section{Data and methodology}

This study is based on museums in the Valencia region of Spain. Existing literature 
shows that innovation performance differs significantly depending on the country where museums are located (Camarero at al. 2011) and cultural policies to which they are subject (Vicente et al. 2012). Therefore, such a focus helps to minimise the impact of the variables 'country' and 'policy' by treating them as control variables.

Located along the Mediterranean coast of the Iberian Peninsula, the Valencian Autonomous Community is the fourth largest Spanish region in terms of both population size and economic volume. Moreover, it is also the largest region of the country by its museographical resources: a total of 206 museums and museographical exhibitions according to the most recent national survey available, from 2016.

To capture a snapshot of what collaboration in Valencian museums is like, we first conducted a questionnaire survey on all 121 museums registered with the Valencia regional government. From 59 valid responses, the survey discovered a notable polarisation, with intensive inter-museum collaboration and collaboration with universities, and limited cross-sectorial collaboration with high-tech firms, museography-oriented firms, individual specialists, and museum associations. It also threw the important conclusion that different collaboration arrangements have different effects on museum innovation depending on the collaborator and the type of innovation (Li and Ghirardi 2019).

Subsequently, we turned to an in-depth multiple case study based on data collected from four local museums by semi-structured interviews and with participant observation, to further explore and identify actual modes of collaboration involved in the process of museum production and innovation. Yin (2009) argued that case studies are a suitable strategy for how-oriented questions, and multiple-case studies deliver more robust than an individual-case study. The selection of cases was largely based on 
theoretical interest and practical convenience. A summary of interviewed museums and interviewees is given in table 1 .

[Insert table 1]

The analysis depended on the analytical framework discussed above and placed particular attention to the process of production and innovation embedded in the four functional activities: i.e., restoration, exhibition, digital museum and visitor services, which reflected technological innovation-dominated production, cultural innovationdominated production, technological innovation-dominated experience, and cultural innovation-dominated experience, respectively. Induction method is utilised to bring together different organisational behaviours in terms of the motivation, shape, and mode of collaboration.

Lastly, and most importantly, the results of the survey were used to assess the effectiveness of the different modes of collaboration identified in the case study. This option was chosen due to its reliability and validity, as survey results were based on data collected from the same population sample as the cases in this study.

\section{Findings from Cross-cases Analysis}

\section{The Overview of Four Cases}

The four were a small municipal natural science museum $(\mathrm{C} 1)$, a medium municipal ethnology museum (C2), a small contemporary art museum affiliated to a private foundation (C3), and a medium private specialized museum (C4). All of them located in Valencia, the capital city of the Valencia region.

Overall, this case study demonstrated that collaboration was widespread in all four museums, but specific collaboration arrangements varied from case to case. Specifically, collaborative activities were strongly dependent on the domain of 
production and innovation as well as the director's attitude toward the idea of collaboration. A brief description of collaboration in all four cases is summarised in table 2.

[Insert table 2]

\section{The Motivation for Collaboration}

Based on the description of the four cases, it is suggested that the main general motivation for collaboration is to make up for a shortage of skilled staff and related knowledge. Most museums suffer from a lack of staff because (1) small museums are staffed by very few employees, e.g., both $\mathrm{C} 1$ and $\mathrm{C} 3$ only had two full-time employees that fulfil a variety of roles; and (2) mid-sized museums had temporary shortages of skilled labour during particularly busy periods, e.g., C2 was understaffed on the preparatory phase of exhibitions, with tight deadlines and large amounts of restoration work required.

Because people are the carriers of knowledge, a staff shortage necessarily implies a shortage of knowledge too. In our cases, small and private museums were not equipped with any professional restorers or IT engineers, so they also lacked analytical and synthetic knowledge capabilities. As shown in an earlier survey on Valencian museums, only $15 \%$ of employees had scientific and engineering backgrounds primarily in biology, conservation or restoration. This further supports the argument that museums are symbolic knowledge-intensive organizations and don't have an affinity with analytical and synthetic knowledge bases on which technological innovations are reliant.

But the configuration of museum personnel doesn't guarantee the presence of all essential knowledge bases. For instance, C2 and C4 relied on external IT contractors for specific work even though they were mid-sized museums and had an IT department. 
Considering the fact that many museographical activities, like restoration and heritage digitalisation, are technology-intensive and require a high degree of specialization, it is possible there is a mismatch between technical abilities required and the technical capabilities of staff, in which case external collaboration could provide a solution.

The third motive might be a consequence of demand-driven innovation. Many directors argued that innovation might support a new strategy aimed at creating value for communities and society and, hence, understanding the needs of community and visitors was the key to success. Taking visitor services as an example: they are involved in any part of a museum where staff can meet the public face to face on a regular basis to provide an informative, pleasant and comfortable visit to museum-goers (Woollard 2004), so at its core, innovation in this area means meeting visitor expectations in terms of quality and accessibility. In our cases, all museums engaged in direct interaction with visitors, onsite and online, to improve visitor services, which might suggest that userproducer interaction is a necessary condition to strengthen demand-driven innovation capabilities.

\section{The Shape of Collaboration}

Despite many different forms, collaborative practises involved in museums can be grouped by induction into four main categories. The first and most frequent is outsourcing. In our study, all museums transferred specific tasks or jobs to external specialists or contracted third-party organisations to source external knowledge and technologies. The outsourced work was mostly technical, auxiliary or service-oriented, such as website development (C3), collection digitalisation (C3), artwork restoration $(\mathrm{C} 2, \mathrm{C} 3)$, infrastructure construction $(\mathrm{C} 1, \mathrm{C} 4)$. Additionally, the turnkey exhibition model adopted by some museums $(\mathrm{C} 1, \mathrm{C} 2, \mathrm{C} 3)$ could also be seen as outsourcing exhibition-making. Note that outsourcing doesn't mean that museums relinquish 
oversight; on the contrary, they remain involved in the co-design, co-work, and decision-making in the implementation process. For instance, museums need to provide a clear brief to the web design agency, decide what exhibits to digitise and the parameters and techniques to be used by IT firms virtualising an exhibition. They are also responsible for exhibition design and installation, even when an independent professional may have been engaged to curate the new exhibition. In other words, collaborative outsourcing (KOT 2008, Ong 2014) benefits knowledge diffusion through supplier-producer interaction, and thus, constitutes an important form of collaboration in museum innovation.

The second form is teamwork, based on the creation of joint project teams, which comprise museum staff as well as external personnel, and where each plays a well-defined role in the delivery of 'a common goal and clear purpose' (Harris and Harris 1996). In this situation, external knowledge is acquired and disseminated through learning by doing in a cooperative environment. $\mathrm{C} 1$ shows a typical example of projectoriented teamwork between a museum and a university in restoration. The university took charge of the design, pilot testing and execution of the repair plan while the director, usually in coordination with the head of the university team, decided the final solutions to be employed, as well as techniques and materials to be adopted, based on the experiment results submitted by the university team.

The third form is consortium, consisting of an association of two or more museums to undertake a common activity, or to achieve a common goal by resourcesharing, as is the case in $\mathrm{C} 3$, which benefited from resource-sharing with other members of the Consortium of Museums of Valencia Community in the areas of artistic production, exhibition programming, educational activities and investigation. A consortium could be established at the national level like ICOM España and Spanish 
Association of Museology, or at the local level like the Consortium of Museums of Valencia Community. Although a consortium constitutes an institutional arrangement to promote collaboration, collaboration is somewhat less frequent than could be expected: (1) only $17 \%$ of Valencia museums belong to professional association, and (2) Spain doesn't have the equivalent of the Museum Association in the UK, or the Museum Alliance in the US, which exert substantial influence in their respective regions. The above three forms of collaboration are based mostly on contractual agreements leading to a relatively stable collaboration mechanism that guarantees effective information exchange and can, therefore, be seen as formal collaborations. Furthermore, these structures are intertwined: the introduction of an itinerant exhibition can be categorised as outsourcing of exhibition planning and design, while production and installation rely on teamwork between the host museum and the exhibition producer, and these exhibitions are often displayed by different members of the consortium.

There is also collaboration based on frequent communication instead of one-off contractual agreements. For example, visitor's preference and tourist appeal were enquired with museum audience face-to-face $(\mathrm{C} 1, \mathrm{C} 2, \mathrm{C} 3, \mathrm{C} 4)$; art viewpoints were shared after private communication between curator and art critics (C4); new approaches to restoration were exchanged directly via telephone communication between restorers from different museums during the course of ordinary work (C2). Peacock (2008) argued that the process of museum innovation is a social construction by conservational interaction for the exchange of internal and external flows of ideas. If this is true, then such interpersonal interaction based on daily conversations should also be considered a form of collaboration. Note that conversational collaboration is different from aimless chatter and refers to dialogue with a specific purpose. Such 
interpersonal conversations are, typically, trust-based, and contribute to overcoming any potential uncertainty and opportunistic behaviours (Lundvall 1988, Chesbrough 2003a).

\section{Collaboration in different types of innovation}

Combining these findings, we can posit different modes of collaboration in the four identified domains according to motivate and form of collaboration, as shown in table 3.

[Insert table 3]

Regarding technology-dominated innovation, in 'restoration' and 'digital museum', collaboration is usually meant to compensate for a deficiency in human resources and analytical/synthetic knowledge. Because these practices usually require highly qualified specialists, rarely present in small and even mid-sized museums, collaboration is mostly based on supplier-producer interaction. Among them, outsourcing is the most common form of collaboration in small and mid-sized museums to adopt external knowledge and technology to underpin innovation.

On the other hand, teamwork is not as frequent as outsourcing because successful teamwork relies on team members who have equivalent financial power or scientific and technological competence (Chesbrough 2003a) that small museums usually lack, so teamwork seems to be an alternative collaboration for some museums.

Additionally, conversational collaboration also exists in the restoration department of some museums to deal with solving-problem innovation in their daily work. However, user-producer interaction is less pervasive than could be expected, even in experience-based technological innovation such as digital museum development, which might imply that the pace of the adoption of new technologies is dictated by the availability of new technologies rather than by user demand.

Production-based cultural innovation, like 'exhibition innovation', is delivered through new exhibition development by a museum itself and also by hosting external 
itinerant exhibitions (e.g. C1, C2, and C3). The latter is consistent with Castañer and Campos's (2002) argument that adopting and programming existing artistic and cultural forms is an important cultural innovation in cultural organizations like theatres and museums.

Collaboration in the process of new exhibition development is mainly demanddriven and reliant on the interaction with potential users of innovation - i.e., the exhibition audience in this case - to communicate information about concepts, values and knowledge of a new exhibition. The audience in an exhibition is not only restricted to the public, but also professional communities (such as art critics, colleagues, and scholars), which explains in part why many curators share their thoughts and viewpoints with art critics and other professional peers during the preparatory phase of an exhibition. These exchanges are often private and informal and built on trust. It is just a coincidence of the theoretical proposition that symbolic knowledge is "reliant on tacit knowledge, craft, and practical skills" that is learnt through interaction in the professional community (Asheim et al. 2007).

Collaboration in the adoption of new exhibitions, however, tries to mitigate deficiency in human and symbolic resources, only because museums that lack such resources and knowledge, particularly small museums, have no choice but to collaborate in order to assemble new exhibitions. Here three scenarios can be identified:

(1) Teamworking with external curators (e.g., independent curators and university professors in many cases) to curate a new exhibition from the museum's collection.

(2) Outsourcing the entire exhibition to other museums or cultural organizations.

(3) Joining externally promoted exhibitions by resource sharing among consortium members. 
All the above collaborations are characterized by a contractual form of supplierproducer interaction.

Finally, all museums are engaged in some form or other of direct interaction with their visitors, onsite and online, meaning that conversational collaboration based on user-producer interaction constitutes the principal mode of collaboration in experience-based cultural innovation.

\section{Not always collaborating}

Museum innovation does not always necessitate external collaboration. Most directors in the interview indicated that curation is nearly a thought experiment-like process involving the personal effort of individual curators, rather than a team effort. For example, the sole curator at $\mathrm{C} 3$ compared his work to mental mapping:

\footnotetext{
"When you read books and the Internet, or visit exhibitions and artists, you draw what you find interesting at just like a conceptual map; then you can arrange these ideas in your own manner through such mental diagrams; after making more of an effort, you might change all that you have planned theoretically and get new ideas totally different from the original" (Interviewee, November 18, 2015, personal interview).
}

The evidence strongly suggests that personal creativity and individual trial-anderror practices are important in the process of curating. This might be because the exhibition curating is a process of codifying tacit symbolic knowledge through a specific storytelling approach and this process usually involves arts and humanities research that attaches great importance to the utilisation of the results of the research for visual presentation. In this process, exhibition curators play a role akin to that of arts and humanity researchers, who are characterised as "lone scholars" (Bakhshi et al. 
2008). In other words, museum staff prefer working alone to collaborating in arts and human researches.

\section{Assessing the effectiveness of the modes of collaboration}

\section{The Basis for Assessment}

Our assessment is conducted on the basis of findings extracted from Author's (2018) study, which was carried out based on the survey data from 59 samples of a small, definite population of 121 museums registered in Valencia Autonomous Community of Spain. The study explored the relations between collaborative arrangement and innovation outcome in Valencian museums based on one-way ANOVA approach, which was utilised to determine if there were differences in innovation outcomes between museums that did, or did not, collaborate with specific actors. The conclusion was reached that the contribution of different collaborative arrangements to museum innovation differs statistically depending on the type of innovation. Specifically, the three main finding on which our assessment is based are generalised as follows:

- Collaboration with universities and high-tech firms, as well as inter-museum collaboration enhance technological innovation.

- Joining professional associations improves cultural innovation.

- Neither technological nor cultural innovation benefits from collaboration with museography-oriented firms or individual specialists.

We utilise these findings as the basis for assessing the effectiveness of the existing modes of collaboration identified above, mainly for the two reasons: (1) the study provides the evidence-based result linking collaborative arrangements and innovation outcomes, and (2) survey results were based on data collected from the same population sample as the cases in this study. 


\section{Results of the Assessment}

As far as technological innovation domain is concerned, teamwork is an effective form of collaboration because the existing teamwork is principally embedded in the interaction between museums and universities, joint working groups involving heritage conservation department of local university for restoration at $\mathrm{C} 1$ are a classic example, which proves that university as an important $R \& D$ institution and technology supplier can play a vital role in facilitating the transfer and adoption of analytical and synthetic knowledge so as to support museums to innovate technologically.

Despite a common practise in all interviewed museums, outsourcing, as an enabler of technological innovation, seems not to be convincing owing to (1) it is applied in a wide range of fields within the museums, from $R \& D$ and restoration to auxiliary and ancillary works; and (2) these works are outsourced to quite diverse collaborators. Given that the majority of outsourced work in museums relates to some specific services, such as artworks restoration at C2 and C3, exhibition installation at $\mathrm{C} 1$ and $\mathrm{C} 4$, and logistics and insurance services at all museums except for $\mathrm{C} 4$ (because toy tin soldiers exhibition is generally small-scale and less valued by its heritage value), and in the form of contracts with museography-oriented firms $(\mathrm{C} 2, \mathrm{C} 3, \mathrm{C} 4)$ and individual specialists (C3), such form of collaboration is sub-optimal for technological and cultural innovation. Conversely, it is more effective for museums to outsource R\&D and other technology-related tasks, like high-stimulation technique adoption at $\mathrm{C} 1$, digitalised exhibition and museum development at C2 and C3, or ICT-based value-added service at $\mathrm{C} 4$, to external technology firms because they are validated facilitators of technological innovation for the museum sectors.

With regards to production-based cultural innovation, joining a consortium is a good way for museums to develop and/or adopt new cultural products, especially for 
small museums like C3, which adopted a collaborative strategy to join the Consortium of Museums of Valencia Community. This is because the consortium is usually institutionalised through the establishment of museum associations and alliances, which constitute an important platform for knowledge-exchange and experience-sharing within the professional network and community. As shown in study case, the membership of museum consortium permitted $\mathrm{C} 3$ to share resources in artistic production, exhibition programming, educational activities and investigations so as to make up for a deficiency of cultural innovation capacity owing to relatively inadequate symbolic knowledge bases.

But the role of teamwork and outsourcing in the process of cultural innovation is still unclear. On the one hand, collaborating with independent curators seems to be common practice in museums today, especially in small and mid-sized museums, but individual specialists do not have a significant role in fostering cultural innovation in museums. On the other hand, just as shown in the cases of $\mathrm{C} 1, \mathrm{C} 2$, and $\mathrm{C} 3$, outsourcing exhibition is often the objective of inter-museum collaboration, which does not contribute to the development of cultural innovation capabilities in museums either. This is also consistent with our empirical observation, from the early innovation survey on Valencian museums, that a majority of local small museums scattered in remote towns and villages are more likely to count on, or even exclusively rely on, external curators for organising new exhibitions, but it, obviously, cannot be concluded that those small museums are more culturally innovative than other large and medium-sized counterparts.

An explanation might be that the introduction of new cultural products, like exhibitions, only contributes to the novelty of "programming" (Castañer and Campos 2002), which is essentially different from the outsourcing of R\&D and the adoption of 
external technologies because the latter requires museums to identify external technologies and incorporate them into their own museographical functions to improve their technological innovation capabilities.

Lastly, it should be mentioned that Li and Ghirardi (2019) study focused exclusively on supplier-producer interaction, which precludes the assessment of collaboration based on user-producer interaction. Cultural innovation in the experience domain is mostly reliant on user-producer interaction wherein conversational collaboration is widely utilised by museums, so the assessment of collaboration for experience-based cultural innovation requires further study in the future.

\section{Conclusion and Implications}

The aim of this study is to explore the existing modes of collaboration involved in the process of production and innovation of museum organisations and further, to assess their effectiveness in facilitating both technological and cultural innovations of museums. To achieve this aim, we developed a four-domain analytical framework matching the type and process of innovation to reflect the peculiarity of museum organisations. By analysing main motives and forms of collaboration based on the multiple case study of four small and medium museums in the city of Valencia, Spain, we may conclude that there are different modes of innovation in the domain of innovation and production of museums.

Specifically, the process of technological innovation, in both, the production and experience domains, is embedded in the creation of analytical and synthetic knowledge, wherein major modes of collaboration are characterised by more formal and institutional forms (e.g., contract) involved in supplier-producer interactions, such as outsourcing and teamwork, with a view to making up for the shortage of manpower and technologies. On the other hand, the process of cultural innovation, no matter in the 
production or experience domain, is based on symbolic knowledge bases, wherein a dominant form of collaborative practices, i.e., conversational collaboration, is more informal between producers and users and consequently, promoting a user-focus and demand-driven innovation.

However, this conclusion is solely a snapshot of museum collaboration, which doesn't reveal if these collaboration modes adopted by museums can improve innovation outcomes or not. To address this issue, we further assess the effectiveness of existing collaboration based on supplier-producer interaction. The result shows that teamwork is an effective form of collaboration for technological innovation, while consortium is beneficial for cultural innovation in the production domain; the strengths and validity of outsourcing will depend on the collaborator - outsourcing to high-tech firms, universities and research centres, rather than individual specialists or museography-oriented firms, can facilitate technological innovation.

These conclusions have some implications for innovation management in museum organisations. First, it is important to favour quality over quantity of collaboration, only effective modes of collaboration can achieve museum innovation. Second, by doing so, the decision to collaborate should be guided by considerations such as what kind of innovation is to be achieved. Third, collaboration is not a shortcut to museum innovation because some innovative activities, like arts and humanities research, are mostly reliant on the museums' own capacity for innovation instead of the adoption of external innovation. 


\section{Reference}

Asheim, B. T. and Coenen, L. (2005) 'Knowledge bases and regional innovation systems: Comparing Nordic clusters', Research Policy, 34(8), pp. 1173-1190. doi: 10.1016/j.respol.2005.03.013.

Asheim, B., Coenen, L. and Vang, J. (2007) 'Face-to-face, buzz, and knowledge bases: Sociospatial implications for learning, innovation, and innovation policy', Environment and Planning C: Government and Policy, 25(5), pp. 655-670. doi: $10.1068 / \mathrm{c} 0648$.

Bakhshi, H., Schneider, P. and Christopher, W. (2008) Arts and Humanities Research and Innovation. London.

Baregheh, A., Rowley, J. and Sambrook, S. (2009) 'Towards a multidisciplinary definition of innovation', Management Decision, 47(8), pp. 1323-1339. doi: 10.1108/00251740910984578.

Bedford, L. (2001) 'Storytelling: The Real Work of Museums', Curator: The Museum Journal, pp. 27-34. doi: 10.1111/j.2151-6952.2001.tb00027.x.

Benkler, Y. (2006) The Wealth of Networks. How Social Production Transforms Markets and Freedom. New Haven: Yale University Press.

Bureth, A., Wolff, S. and Zanfei, A. (1997) 'The two faces of learning by cooperating: The evolution and stability of inter-firm agreements in the European electronics industry', Journal of Economic Behavior \& Organization, 32, pp. 519-537. doi: 10.1016/S0167-2681(97)00009-7.

Camarero, C. and Garrido, M. J. M. J. (2012) 'Fostering Innovation in Cultural Contexts: Market Orientation, Service Orientation, and Innovations in Museums', Journal of Service Research, 15(1), pp. 39-58. doi: $10.1177 / 1094670511419648$.

Camarero, C., Garrido, M. J. and Vicente, E. (2011) 'How cultural organizations' size and funding influence innovation and performance: the case of museums', Journal of Cultural Economics, 35(4), pp. 247-266. doi: 10.1007/s10824-0119144-4.

Castañer, X. (2014) 'Cultural Innovation by Cultural Organizations', in Ginsburgh, V. A. and Throsby, D. (eds) Handbook of the Economics of Art and Culture, Volume 2. Elsevier, pp. 263-276. doi: 10.1016/B978-0-444-53776-8.00011-8. 
Castañer, X. and Campos, L. (2002) 'The Determinants of Artistic Innovation: Bringing in the Role of Organizations', Journal of Cultural Economics, 26, pp. 29-52.

Castro-Martínez, E. and Fernández-Baca Casares, R. (2012) La innovación en patrimonio cultural: un espacio de confluencia de diversas bases de conocimiento. No 2012/07. Valencia.

Castro-Martínez, E., Recasens, A. and Jiménez-Sáez, F. (2013) 'Innovation systems in motion: an early music case', Management Decision, 51(6), pp. 1276-1292. doi: 10.1108/MD-11-2011-0433.

Chesbrough, H. W. (2003a) Open innovation: The New Imperative for Creating and Profiting from Technology. Boston: Harvard Business School Press.

Chesbrough, H. W. (2003b) ‘The era of open innovation', MIT Sloan Management Review, 44(3), pp. 35-41.

Compagnucci, L. and Spigarelli, F. (2018) 'Fostering Cross-Sector Collaboration to Promote Innovation in the Water Sector', Sustainability, 10(11), pp. 41-54. doi: $10.3390 /$ su10114154.

Costa Barbosa, C. (2013) Innovation in Museums through the Use of ICTs. University of Oslo, Autonomous University of Madrid.

De-Miguel-molina, B., Hervás-oliver, J. L. and Boix, R. (2013) 'Drivers of Beautiful Innovation: Artworks Restoration by Museums', in 35th DRUID Conference. Barcelona.

Fagerberg, J. (2006) 'Innovation: A Guide to the Literature', in Fagerberg, J., Mowery, D., and Nelson, R. (eds) The Oxford Handbook of Innovation. Oxford: Oxford University Press, pp. 1-26.

Freeman, C., Clark, J. and Soete, L. (1982) Unemployment and Technical Innovation: A Study of LongWaves and Economic Development. London: Pinter.

Galloway, S. and Dunlop, S. (2007) 'A Critique of Definitions of the Cultural and Creative Industries in Public Policy', International Journal of Cultural Policy, 13(1), pp. 1477-2833. doi: 10.1080/10286630701201657.

Granados, C. and Pareja-Eastaway, M. (2019) 'How do collaborative practices contribute to innovation in large organisations? The case of hackathons', Innovation, pp. 1-19. doi: 10.1080/14479338.2019.1585190.

Handke, C. W. (2004) 'Defining Creative Industries by Comparing the Creation of 
Novelty.' In Creative Industries: A Measure for Urban Development?

Vienna: FOKUS \& WIWIPO

Harkema, S. J. M. (2003) 'Learning in Innovation Projects: An Approach Based on Complexity Theory', in The Fourth European Conference on Organizational Knowledge, Learning, and Capabilities. Barcelona.

Harris, P. R. and Harris, K. G. (1996) 'Managing effectively through teams', Team Performance Management: An International Journal, 2(3), pp. 23-36. doi: $10.1108 / 13527599610126247$.

Hauknes, J. (1998) Services in innovation - Innovation in services. Oslo.

Herreman, Y. (2004) 'Display, Exhibits and Exhibitions', in Boylan, P. J. (ed.) Running a Museum: a Practical Handbook. Paris: ICOM, pp. 91-103.

ICOM-CC (no date) Conversation: who, what \& why?

Johnson, P. and Thomas, B. (1998) 'The Economics of Museums: A Research Perspective', Journal of Cultural Economics, 22(22), pp. 75-85. doi: 10.1023/A:1007537500352.

Kobarg, S., Stumpf-Wollersheim, J. and Welpe, I. M. (2019) 'More is not always better: Effects of collaboration breadth and depth on radical and incremental innovation performance at the project level', Research Policy, 48(1), pp. 1-10. doi: 10.1016/j.respol.2018.07.014.

KOT, S. (2008) 'Collaboration in logistics outsourcing relations', in Stefko, R. and Frankowsky, M. (eds) Management 2008: in times of global change and uncertainty: (part. I). Prešov: University of Prešov, pp. 88-95.

Li, C. and Ghirardi, S., (2018). The role of collaboration in innovation at cultural and arts organisations: the case of museums. Museum Management and Curatorship. 34 (3), 273-289.

Lundvall, B.-Å. (1988) 'Innovation as an interactive process: from user-producer interaction to the national system of innovation', in Dosi, G. et al. (eds) Technical Change and Economic Theory. London: Pinter Publishers, pp. 349-369.

Malerba, F. and Orsenigo, L. (1995) 'Schumpeterian patterns of innovation', Cambridge Journal of Economics, 19, pp. 47-65. doi:

10.1093/oxfordjournals.cje.a035308.

Martin, R. and Moodysson, J. (2011) 'Innovation in Symbolic Industries: The Geography and Organization of Knowledge Sourcing Roman', European 
Planning Studies, 197(October 2014), pp. 1183-1203. doi: 10.1080/09654313.2011.573131.

Miles, I. and Green, L. (2008) Hidden innovation in the creative industries. London: NESTA.

OECD and Eurostat (2005) Oslo Manual: guidelines for collecting and interpreting innovation data, OECD publicshing. Paris.

Ong, B. G. (2014) Collaborative Outsourcing and Partnerships: The Changi Experience. Singapore.

Peacock, D. (2008) 'Making Ways for Change: Museums, Disruptive Technologies and Organisational Change', Museum Management and Curatorship, 23(4), pp. 333-351. doi: 10.1080/09647770802517324.

Plessis, M. D. (2007) ‘The role of knowledge management in innovation', Journal of Knowledge Management, 11(4), pp. 20-9.

Ruiz-Torres, A. J. et al. (2018) 'Logistic services in the Caribbean region', Academia Revista Latinoamericana de Administración, 31(3), pp. 534-552. doi: 10.1108/ARLA-03-2017-0078.

Scott, A. J. (2004) 'Cultural-Products Industries and Urban Economic Development: Prospects for Growth and Market Contestation in Global Context', Urban Affairs Review, 39(4), pp. 461-490. doi: 10.1177/1078087403261256.

Schroth, F. and Häußermann, J. J. (2018) 'Collaboration Strategies in Innovation Ecosystems: An Empirical Study of the German Microelectronics and Photonics Industries', Technology Innovation Management Review, 8(11), pp. 4-12. doi: 10.22215/timreview/1195.

Stoneman, P. (2010) Soft Innovation: Economics, Product Aesthetics and the Creative Industies. New York: Oxford University Press Inc.

Sundbo, J. (2009) 'Innovation in the experience economy: a taxonomy of innovation organisations', The Service Industries Journal, 29(4), pp. 431-455. doi: 10.1080/02642060802283139.

Thomson, A. M., Perry, J. L. and Miller, T. K. (2009) 'Conceptualizing and measuring collaboration', Journal of Public Administration Research and Theory, 19(1), pp. 23-56. doi: 10.1093/jopart/mum036.

UNCTAD (2008) Creative Economy Report 2008, United Nations. Geneva. 
Verbano, C. et al. (2008) 'Characteristics of Italian art restoration firms and factors influencing their adoption of laser technology', Journal of Cultural Economics, 32, pp. 3-34. doi: 10.1007/s10824-007-9053-8.

Vicente, E., Camarero, C. and Garrido, M. J. (2012) 'Insights into Innovation in European Museums', Public Management Review, 14(5), pp. 649-679. doi: 10.1080/14719037.2011.642566.

Woollard, V. (2004) 'Caring for the Visitor', in Boylan, P. J. (ed.) Running a Museum: a Practical Handbook. Paris: ICOM, pp. 105-118.

Yin, R. K. (2009) Case Study Research: Design and Methods (fourth edition). Los Angeles: Sage Publications.

Zukauskaite, E. (2012) 'Innovation in cultural industries: The role of university links', Innovation, 14(3), pp. 404-415. doi: 10.5172/impp.2012.14.3.404. 


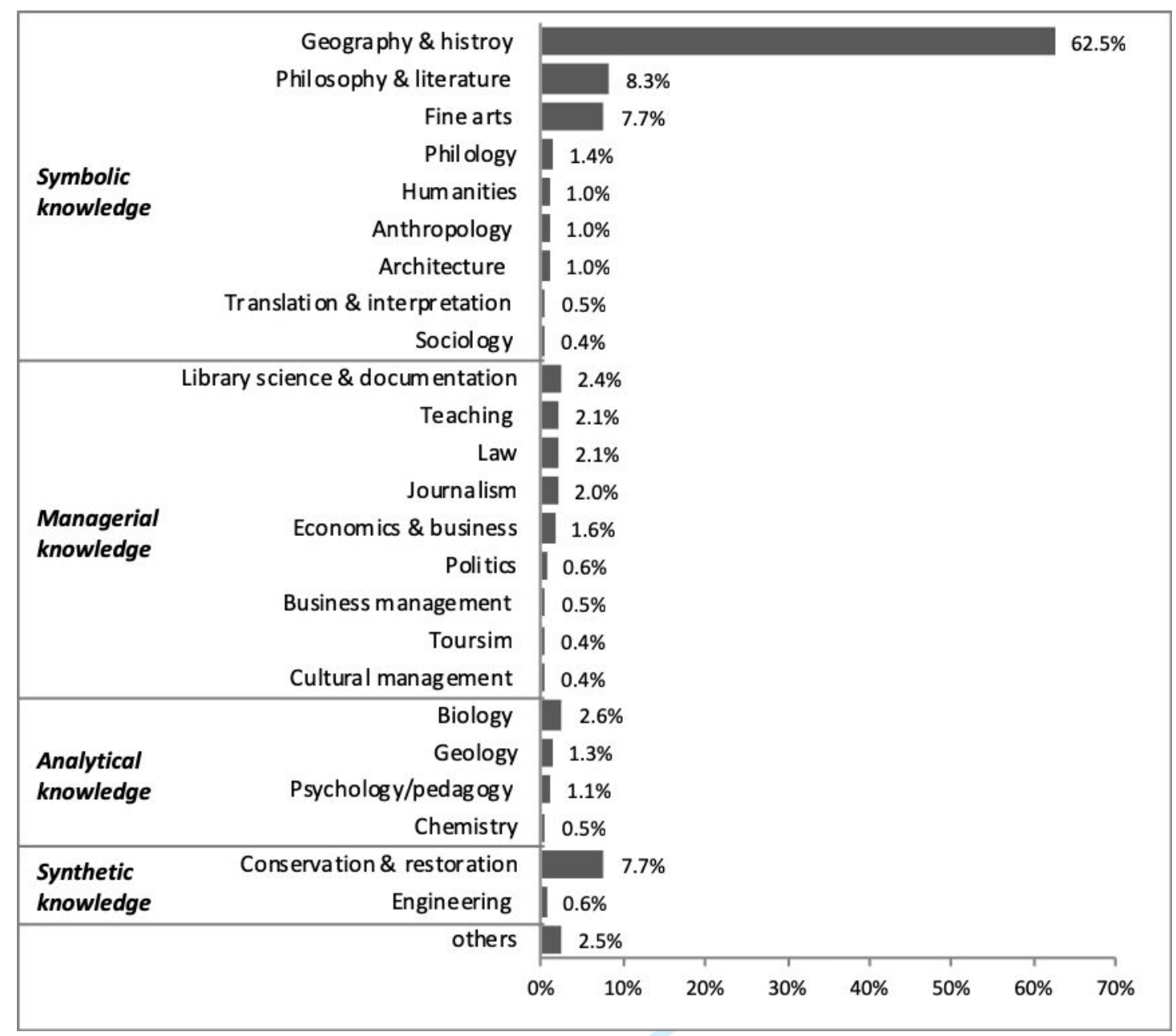

Figure 1 Knowledge bases of Spanish museums

Source: Ministerio de Educación, Cultura y Deporte 2012 
Figure 2 Four domains of the production and innovation of the museum organisation 
Table 1 The summery of interviewed museums and interviewees.

\begin{tabular}{|c|c|c|c|c|c|c|}
\hline \multicolumn{4}{|c|}{ Museum } & \multicolumn{3}{c|}{ Interview } \\
\hline Case & Type & Ownership & Staff no. & Interviewee & Date & $\begin{array}{c}\text { Length } \\
\text { (min.) }\end{array}$ \\
\hline C1 & Natural history & Municipal & 2 & Director & $05 / 02 / 2017$ & 42 \\
\hline C2 & Ethnology & Municipal & 24 & Director & $20,21 / 10 / 2015$ & 120 \\
\hline C3 & Contemporary arts & Private & 2 & $\begin{array}{c}\text { Deputy } \\
\text { director }\end{array}$ & $18 / 11 / 2015$ & 37 \\
\hline C4 & Specialised & Private & 10 & Director & $13 / 11 / 2015$ & 110 \\
\hline
\end{tabular}

Table 2 The description of four cases

\begin{tabular}{|c|c|c|c|c|}
\hline & $\mathrm{C1}$ & $\mathrm{C2}$ & C3 & $\mathbf{C 4}$ \\
\hline Type & Natural science & Ethnology & Contemporary arts & $\begin{array}{l}\text { Specialised collection of } \\
\text { toy tin soldiers }\end{array}$ \\
\hline Ownership & Municipal government & Municipal government & Private & Private \\
\hline Size & $\begin{array}{l}\text { Only } 2 \text { staff, one of whom is } \\
\text { a contract worker from a } \\
\text { private company. } \\
\text { The director takes up } \\
\text { multiple roles as registrar, } \\
\text { conservator, and curator. }\end{array}$ & $\begin{array}{l}24 \text { staff, over a half of } \\
\text { whom are conservators } \\
\& \text { restorers in the } \\
\text { restoration and } \\
\text { investigation } \\
\text { department. }\end{array}$ & $\begin{array}{l}\text { Only } 2 \text { staff take } \\
\text { responsibility for } \\
\text { museum's daily } \\
\text { operation. }\end{array}$ & $\begin{array}{l}10 \text { staff; the collector - } \\
\text { who is the director, } \\
\text { curator, and restorer - } \\
\text { plays a decisive role in } \\
\text { the museum } \\
\text { management. }\end{array}$ \\
\hline Restoration & $\begin{array}{l}\text { Rely exclusively on project- } \\
\text { based working team } \\
\text { involving professors and } \\
\text { students from local } \\
\text { universities. }\end{array}$ & $\begin{array}{l}\text { Outsource a part of } \\
\text { works to professional } \\
\text { restoration companies } \\
\text { because of the understaff } \\
\text { of restorers, especially } \\
\text { when facing a large } \\
\text { amount of work and } \\
\text { approaching deadline, } \\
\text { esp. only days before the } \\
\text { inauguration of } \\
\text { exhibitions. }\end{array}$ & $\begin{array}{l}\text { No full-time restores. } \\
\text { It only contracts an } \\
\text { independent restorer } \\
\text { temporarily when } \\
\text { objects need to be } \\
\text { restored }\end{array}$ & $\begin{array}{l}\text { Rely exclusively on } \\
\text { internal R\&D because } \\
\text { the restoration of tin } \\
\text { soldiers is a marginal } \\
\text { subject totally different } \\
\text { from that of other } \\
\text { ordinary arts and } \\
\text { heritage objects and } \\
\text { there's no prior } \\
\text { experience to learn from. }\end{array}$ \\
\hline Digital & High-stimulation exhibits & The utilisation of digital & Staff only take up & The director takes up all \\
\hline
\end{tabular}



1

\begin{tabular}{|c|c|c|c|c|}
\hline museum & $\begin{array}{l}\text { that allow visitors to feel a } \\
\text { real sense of exhibits } \\
\text { through touching, developed } \\
\text { by the company Olorama. } \\
\text { Unavailability of museum } \\
\text { website owing to the } \\
\text { shortage of budget and } \\
\text { manpower. }\end{array}$ & $\begin{array}{l}\text { technology is modest, } \\
\text { and only effort has been } \\
\text { devoted to an interactive } \\
\text { game in the website with } \\
\text { the help of a local } \\
\text { technology partners. }\end{array}$ & $\begin{array}{l}\text { system maintenance and } \\
\text { content update that don't } \\
\text { ask for the expertise of } \\
\text { IT. } \\
\text { External information } \\
\text { technology suppliers are } \\
\text { contracted for all IT- } \\
\text { related platform } \\
\text { constructions, e.g., } \\
\text { website and an on-going } \\
\text { digital project } \\
\text { concerning 3D-oriented } \\
\text { virtual exhibition. }\end{array}$ & $\begin{array}{l}\text { IT-related works ranging } \\
\text { from constructing and } \\
\text { maintaining website to } \\
\text { making and posting } \\
\text { contents at social media } \\
\text { because of his in-depth } \\
\text { knowledge and prior } \\
\text { working experience as } \\
\text { IT engineer, except for } \\
\text { the collaboration with } \\
\text { the Vodafone } \\
\text { Foundation to equip } \\
\text { wireless infrastructure } \\
\text { under partnership } \\
\text { agreement. }\end{array}$ \\
\hline Exhibition & $\begin{array}{l}\text { Most exhibitions are } \\
\text { planned and interpreted by } \\
\text { the director herself on the } \\
\text { basis of her own interests. } \\
\text { Some exhibitions are } \\
\text { 'ready-made' introduced } \\
\text { from other museums. }\end{array}$ & $\begin{array}{l}\text { Collection rental and } \\
\text { exhibits on loan are } \\
\text { stressed to facilitate the } \\
\text { production of new } \\
\text { content in permanent } \\
\text { exhibitions, as well as } \\
\text { introducing external } \\
\text { exhibitions to enrich } \\
\text { exhibition programme of } \\
\text { the museum. }\end{array}$ & $\begin{array}{l}\text { The sole curator makes } \\
\text { his own effort to develop } \\
\text { Collection-based } \\
\text { exhibition under } \\
\text { different themes. } \\
\text { The membership of the } \\
\text { Consortium of Museums } \\
\text { of Valencia Community } \\
\text { helps it to engage in } \\
\text { close collaboration with } \\
\text { other members to share } \\
\text { resources in artistic } \\
\text { production, exhibition } \\
\text { programming, } \\
\text { educational activities } \\
\text { and investigation. }\end{array}$ & $\begin{array}{l}\text { The director works as a } \\
\text { typical "lone scholar" } \\
\text { immersed in books } \\
\text { because curating a new } \\
\text { exhibition consists of } \\
\text { historical research about } \\
\text { fashion, customs, social } \\
\text { outlook, etc. in this case. } \\
\text { But he also asks for } \\
\text { advice and help from } \\
\text { specialists with whom he } \\
\text { has a longstanding } \\
\text { friendship. }\end{array}$ \\
\hline $\begin{array}{l}\text { Visitor } \\
\text { service }\end{array}$ & $\begin{array}{l}\text { Regular satisfaction surveys } \\
\text { and face-to-face } \\
\text { communication with onsite } \\
\text { visitors conducted by the } \\
\text { director. }\end{array}$ & $\begin{array}{l}\text { Interact directly with } \\
\text { visitors to track their } \\
\text { preference and needs } \\
\text { through claims and } \\
\text { suggestion system. }\end{array}$ & $\begin{array}{l}\text { "Dynamic visits" } \\
\text { approach is developed to } \\
\text { strengthen visitor } \\
\text { engagement. } \\
\text { Visitor surveys ad } \\
\text { suggestion box are used } \\
\text { to evaluate and improve } \\
\text { visitor service. }\end{array}$ & $\begin{array}{l}\text { Collect feedback } \\
\text { through online and } \\
\text { onsite interaction with } \\
\text { visitors. }\end{array}$ \\
\hline
\end{tabular}


Table 3 The matrix of collaboration modes in terms of four domains of production and innovation of the museum

\begin{tabular}{|c|c|c|c|c|}
\hline Domain & \begin{tabular}{|l|} 
Production-based \\
technological \\
innovation
\end{tabular} & $\begin{array}{l}\text { Experience-based } \\
\text { technological } \\
\text { innovation }\end{array}$ & $\begin{array}{l}\text { Production-based } \\
\text { cultural innovation }\end{array}$ & $\begin{array}{l}\text { Experience-based } \\
\text { cultural innovation }\end{array}$ \\
\hline $\begin{array}{l}\text { Functional } \\
\text { works }\end{array}$ & Restoration & Digital museum & Exhibition & Visitor service \\
\hline $\begin{array}{l}\text { Collaboration } \\
\text { motive }\end{array}$ & $\begin{array}{l}\text { 1. Supplement } \\
\text { manpower } \\
\text { 2. Making up for the } \\
\text { scarcity of } \\
\text { analytical/synthetic } \\
\text { knowledge }\end{array}$ & $\begin{array}{l}\text { 1. Supplement } \\
\text { manpower } \\
\text { 2. Making up for the } \\
\text { scarcity of } \\
\text { analytical/synthetic } \\
\text { knowledge }\end{array}$ & $\begin{array}{l}\text { 1. Improving demand- } \\
\text { driven innovation } \\
\text { 2. Supplement } \\
\text { manpower }\end{array}$ & $\begin{array}{l}\text { Improving demand- } \\
\text { driven innovation }\end{array}$ \\
\hline $\begin{array}{l}\text { Collaboration } \\
\text { form }\end{array}$ & $\begin{array}{l}\text { 1. Outsourcing } \\
\text { 2. Teamwork } \\
\text { 3. Conversation }\end{array}$ & $\begin{array}{l}\text { 1. Outsourcing } \\
\text { 2. Teamwork }\end{array}$ & $\begin{array}{l}\text { 1. Conversation } \\
\text { 2. Teamwork } \\
\text { 3. Outsourcing } \\
\text { 4. Consortium }\end{array}$ & 1. Conversation \\
\hline
\end{tabular}




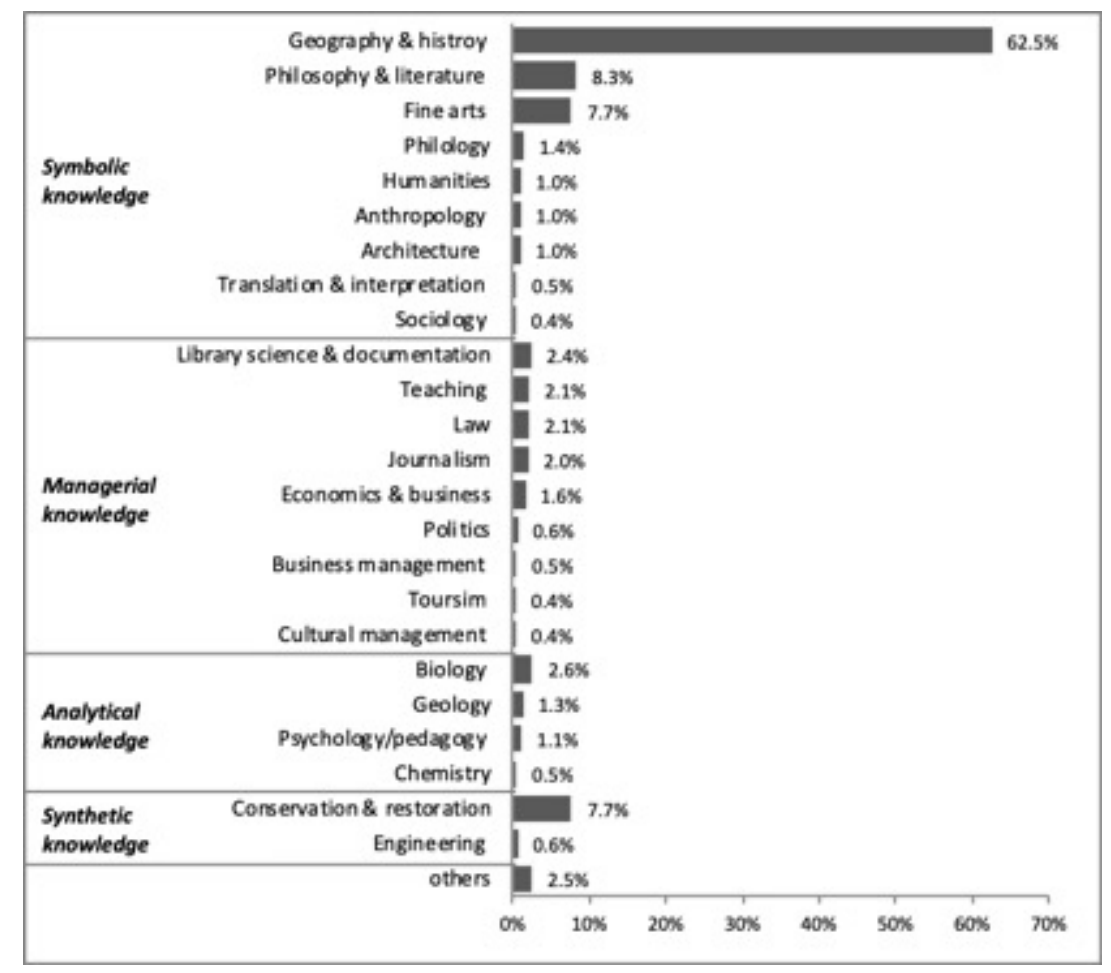

Figure 1 Knowledge bases of Spanish museums Source: Ministerio de Educación, Cultura y Deporte 2012

\section{$146 \times 129 m m(72 \times 72$ DPI)}




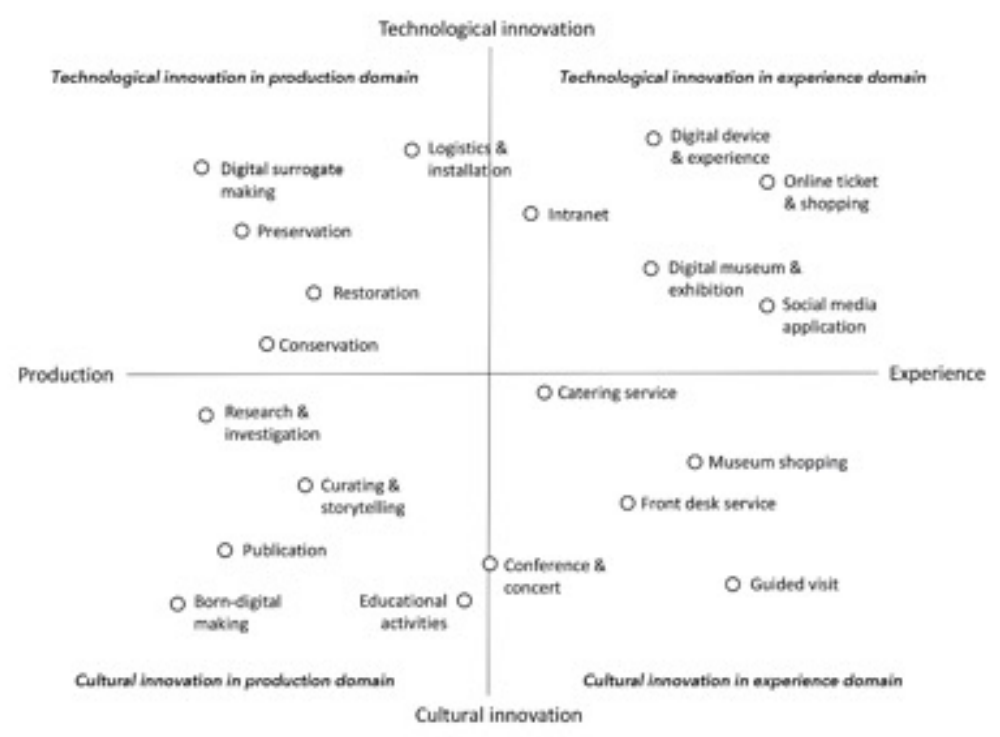

Figure 2 Four domains of the production and innovation of the museum organisation

$149 \times 112 \mathrm{~mm}(72 \times 72 \mathrm{DPI})$ 